\author{
Jurnal E-Bis (Ekonomi-Bisnis) \\ Vol. 4 No. 2 (2020) pp. 179-191 \\ https://jurnal.politeknik-kebumen.ac.id/index.php/E-Bis \\ p-ISSN : 2580-2062 e-ISSN : 2622-3368
}

\title{
Pengaruh Kompensasi dan Pemberdayaan Terhadap Loyalitas Dengan Kepuasan Kerja Sebagai Variabel Intervening
}

\author{
Dani Rizana \\ Manajemen, STIE Putra Bangsa Kebumen, Indonesia, 54360 \\ *Email: danirizana@gmail.com \\ Doi : https://doi.org/10.37339/jurnal e-bis.v4i2.222
}

Diterbitkan oleh Politeknik Dharma Patria Kebumen

\section{Info Artikel}

Diterima :

04-05-2020

Diperbaiki :

10-11-2020

Disetujui :

10-11-2020

\begin{abstract}
ABSTRAK
Penelitian ini bertujuan untuk menganalisis pengaruh kompensasi dan pemberdayaan terhadap Loyalitas dengan kepuasan kerja sebagai variabel intervening. Penelitian ini menggunakan metode analisis deskriptif kuantitatif dengan bantuan program SPSS 25. Dalam metode statistika, dilakukan uji validitas, reliabilitas, pengujian asumsi klasik dan analisis jalur, uji t dan analisis korelasi. Sampel dalam penelitian ini sebanyak 35 responden dengan teknik pengambilan sampel jenuh dengan pengumpulan data menggunakan kuesioner. Pengujian Hipotesis pada analisis jalur variabel kompensasi berpengaruh positif terhadap kepuasan kerja dan variabel pemberdayaan berpengaruh positif terhadap kepuasan kerja dengan kontribusi $75,7 \%$. Pengujian Hipotesis pada analisis jalur persamaan II variabel pemberdayaan tidak berpengaruh positif terhadap loyalitas, variabel kompensasi berpengaruh positif terhadap loyalitas dan variabel kepuasan kerja berpengaruh positif terhadap loyalitas dengan kontribusi 73,5\%.

Kata Kunci: Kompensasi, Pemberdayaan, Kepuasan, Loyalitas.
\end{abstract}

\begin{abstract}
This study aims to analyze the effect of compensation and empowerment on loyalty with job satisfaction as an intervening variable. This study uses a quantitative descriptive analysis method with the help of the SPSS 25 program. In statistical methods, validity, reliability, classical assumption testing and path analysis, $t$ test and correlation analysis are carried out. The sample in this study were 35 respondents. The sampling technique was saturated with data collection using a questionnaire. Hypothesis testing on the path analysis of the compensation variable has a positive effect on job satisfaction and the empowerment variable has a positive effect on job satisfaction with a contribution of $75.7 \%$. Hypothesis testing on equation path analysis II, empowerment variables do not have a positive effect on loyalty, the compensation variable has a positive effect on loyalty and the job satisfaction variable has a positive effect on loyalty with a contribution of $73.5 \%$

Keywords: Compensation, Empowerment, Satisfaction, Loyalty.
\end{abstract}


Alamat Korespondensi : $\quad$ Jl. Letnan Jenderal Suprapto No.73 Kebumen, Jawa Tengah, Indonesia 55431

\section{PENDAHULUAN}

Setiap organisasi mempunyai cara masing-masing dalam memanajemen sumber daya manusianya, terutama dalam hal menciptakan rasa nyaman dalam bekerja. Hal ini sangatlah wajar karena perasaan nyaman yang dimiliki oleh seorang karyawan akan berimbas pada kinerja karyawan itu sendiri. Apabila para karyawan merasa nyaman di tempat dia bekerja, maka kinerja karyawan akan lebih baik dari pada karyawan yang tidak dengan perasaan nyaman. Manajemen sumber daya manusia merupakan suatu kegiatan atau suatu sistem manajemen yang mengadakan dan mengelola sumber daya manusia yang siap, bersedia, dan mampu memberikan konstribusi yang baik agar dapat bekerja sama secara efektif untuk mencapai tujuan baik secara individu maupun secara organisasi menurut Hasibuan (2016:10). Peran sumber daya manusia merupakan salah satu faktor yang sangat penting, karena organisasi tidak bisa berjalan dengan baik tanpa didukung oleh konstribusi sumber daya manusia yang memadai baik di tinjau dari sisi kualitas maupun kuantitas (Mondy, 2008).

Perkembangan perekonomian yang semakin pesat, mengharuskan setiap organisasi untuk meningkatkan daya saing agar dapat tetap bertahan dan mencapai tujuan organisasi. Dalam pencapaian ini dibutuhkan kontribusi sumber daya manusia untuk menjalankan fungsi-fungsi manajemen organisasi. Kontribusi yang dibutuhkan organisasi dari pegawainya tentu tidak hanya berupa kontribusi tenaga, melainkan juga kontribusi konseptual, dan rasa setia karyawan pada organisasinya. Rasa setia yang dirasakan pegawai terhadap organisasi tidak dapat dibangun dengan mudah oleh organisasi, sehingga organisasi harus dapat menjaga dan mempertahankan pegawai melalui balas jasa/imbalan atas kontribusinya. Rasa setia ini merupakan sebuah loyalitas kerja pegawai terhadap organisasi. Organisasi harus memberikan perhatian yang sungguh-sungguh kepada pegawai sehingga loyalitas kerja pegawai dapat dipertahankan.

Hasibuan (2007) mengemukakan bahwa loyalitas kerja atau kesetiaan merupakan salah satu unsur yang digunakan dalam penilaian pegawai yang mencakup kesetiaan terhadap pekerjaannya, jabatannya dan organisasi. Kesetiaan ini dicerminkan oleh kesediaan pegawai menjaga dan membela organisasi di dalam maupun di luar pekerjaan dari rongrongan orang yang tidak bertanggung jawab. Menurut Dessler (2000) loyalitas pegawai merupakan sikap emosional yang menyenangkan dan mencintai pekerjaannya, Sehingga seorang yang memiliki loyalitas dalam bekerja bersedia bekerja lembur untuk menyelesaikan pekerjaan yang dicintai dan disenangi olehnya.

Sikap loyalitas dalam organisasi diperlukan agar pegawai dapat bekerja untuk dirinya sendiri dan bekerja dalam tim untuk kepentingan bersama anggota organisasi tersebut yang pada akhirnya dapat mempengaruhi pegawai untuk memilih bekerja lembur, bekerja pada akhir pekan dan pindah ke lokasi lainnya untuk loyal pada pekerjaannya (Robbin dan Coulter, 2016). Tindakan loyalitas dalam tim dapat diwujudkan dengan cara melakukan kerja sama yang merupakan tujuan tim dan kemauan untuk mengeluarkan jumlah energi yang luar biasa untuk mencapai tujuan-tujuan tersebut. Anggota tim yang efektif menunjukkan loyalitas dan dedikasi yang intens untuk tim serta bersedia melakukan apa pun untuk membantu tim mereka berhasil (Robbin dan Coulter, 2016). Apabila organisasi sudah mendapatkan loyalitas dari pegawainya, maka sepatutnya organisasi memberikan timbal balik yang baik yaitu berupa reputasi dan karir yang stabil serta kompensasi yang cukup, sehingga kepuasan kerja yang didapatkan pegawai 
dapat menimbulkan rasa cinta pada pekerjaan dan organisasi.

Menurut Handoko (1998:155) kompensasi adalah segala sesuatu yang diterima para pegawai sebagai balas jasa untuk pekerjaan mereka. Kompensasi yang diberikan perusahaan kepada pegawai dapat memberikan manfaat jangka panjang dan pendek perusahaan karena kompensasi berfungsi dan bertujuan untuk ikatan kerjasama organisasi dengan pegawai, peningkatan Loyalitas pegawai, pengadaan yang efektif, memotivasi, menjaga stabilitas pegawai, menjaga kedisiplinan pegawai. (Ardana, dkk., 2012:154). Kompensasi dapat menyediakan peluang pertumbuhan kepada pegawai dan menciptakan persaingan yang kuat di antara pegawai dalam rangka memiliki dorongan untuk bekerja lebih efisien dan mahir (Khan et al, 2011). Masalah kompensasi sangat penting sebab kompensasi merupakan dorongan utama seseorang mau menjadi pegawai dari suatu perusahaan dan dapat memberikan semangat kerja.

Kompensasi berpengaruh terhadap produktifitas pegawai. Semakin besar kompensasi yang diterima oleh pegawai dapat meningkatkan produktifitas pegawai. Sebaliknya rendahnya kompensasi dapat menyebabkan pegawai malas bekerja, timbul keresahan dalam organisasi dan pada akhirnya aktifitas organisasi dapat terganggu, sehingga kompensasi bukanlah masalah yang sederhana, oleh karena itu diperlukan suatu pedoman yang tepat dalam penentuannya. Tepat bukan hanya pada waktu pemberiannya akan tetapi juga jumlahnya. Pemberian kompensasi yang tepat akan meningkatkan Loyalitas pegawai, melalui kompensasi organisasi dapat mempertahankan sumber daya manusia yang dimiliki. Dengan kompensasi yang cukup maka pegawai dapat memenuhi kebutuhan hidupnya sehingga semakin besar kompensasi yang diberikan berati pegawai tersebut akan dapat memperoleh ketenangan dalam melaksanakan pekerjaan mereka. Menurut Rahmadana (2015) semakin tinggi kompensasi yang didapatkan pegawai maka dapat meningkatkan loyalitas terhadap organisasi.

Selanjutnya faktor lain yang mempengaruhi Loyalitas pegawai adalah Pemberdayaan. Menurut Gibson, dkk (2012:508), Pemberdayaan adalah memberi izin kepada pegawai untuk membuat keputusan untuk mengerjakan beban kerja tepat waktu. Menurut Schermerhorn, dkk (2012:275), Pemberdayaan adalah proses dimana manajer membantu orang lain untuk memperoleh dan menggunakan kekuatan yang dibutuhkan membuat keputusan yang mempengaruhi diri mereka dan pekerjaan mereka. Dari beberapa konsep di atas, maka dapat disimpulkan bahwa pemberdayaan adalah tindakan yang dilakukan oleh pimpinan terhadap pegawai dalam memberikan otoritas mengalami lebih banyak penentuan nasib sendiri, makna, kompetensi, dan dampak mengenai peran mereka dalam organisasi. dengan indikator-indikator: (1) pelibatan dalam pengambilan keputusan, (2) pemberian kesempatan pegawai untuk pengembangan diri, (3) pemberian otoritas dalam menjalankan tugas, (4) tanggung jawab.

Menurut Widayati (2018) Keterlibatan dan rasa tanggung jawab akan selalu ada jika pegawai terlibat langsung dengan tugas tugas organisasi dan otoritas dalam mengambil keputusan. Perasaan perasaan inilah yang dapat menumbuhkan loyalitas kepada organisasi. Dengan melibatkan diri didalam organisasi pegawai akan mengetahui arah dan tujuan organisasi. Sebaiknya pegawai didorong agar dapat memberikan ide-ide, usulan-usulan dan program program mereka guna mencapai tujuan organisasi, sehingga pegawai dapat mengontrol pekerjaannnya dan mendorong untuk lebih kreatif dan inovatif Alasannya, Dengan adanya pemberdayaan pegawai yang diikutsertakan dalam mengambil suatu kebijakan yang dapat menentukan tercapai atau tidaknya tujuan organisasi. Dengan adanya pemberdayaan di suatu 
organisasi pegawai akan memiliki rasa memiliki yang tinggi terhadap pekerjaan dan merasa dirinya berarti bagi organisasi.

Pada penelitian yang dilakukan oleh Ester et al (2018) mengenai pengaruh pemberdayaan dan kepercayaan terhadap Loyalitas didapatkan hasil yang menyatakan bahwa pemberdayaan memberikan pengaruh langsung positif terhadap Loyalitas. Hasil lain mengungkapkan persepsi pegawai terhadap pemberdayaan berdampak pada loyalitas pegawai.

Variabel yang memediasi adalah kepuasan kerja. Menurut Rizwan et al (2014) menyatakan semakin pegawai merasa puas atas hasil kerjanya maka mereka akan semakin loyal terhadap organisasi. Kepuasan kerja merupakan keadaan emosional yang menyenangkan atau tidak menyenangkan oleh para pegawai mengenai pekerjaannya (Mangkunegara, 2000: 122, dalam Sinollah,2011). Menurut Davis dan Newstrom (1985:105) mendeskripsikan kepuasan kerja adalah seperangkat perasaan pegawai tentang menyenangkan atau tidaknya pekerjaan mereka. Tinggi rendahnya kepuasan kerja ditentukan oleh pengawasan, rekan kerja, gaji, promosi, dan pekerjaan itu sendiri (Tsaidan Huang, 2008; dalam Widyanti, dkk., 2016). Pegawai merasa puas dengan fasilitas yang ada pada tempat kerja mereka dengan kondisi kerja yang baik pegawai akan merasa nyaman serta dengan rekan kerja yang mendukung setiap pekerjaan mereka, selain itu kenaikan tamsil setiap dua tahun sekali juga mempengaruhi tingkat kepuasan pegawai.

Usaha pemberian kompensasi dan pemberdayaan pegawai dimaksudkan agar pegawai dapat memusatkan perhatian sepenuhnya pada pelaksanaan tugas-tugas yang dibebankan kepadanya. serta apabila kesejahteraan pegawai telah tercapai kepuasan Kerja juga akan meningkat dan Loyalitas pada pekerjaannya akan meningkat, sehingga akan terwujud aparatur pemerintah yang bersih, berwibawa, berdayaguna, berkualitas tinggi, dan sadar akan tanggungjawabnya untuk melaksanakan tugas-tugasnya.

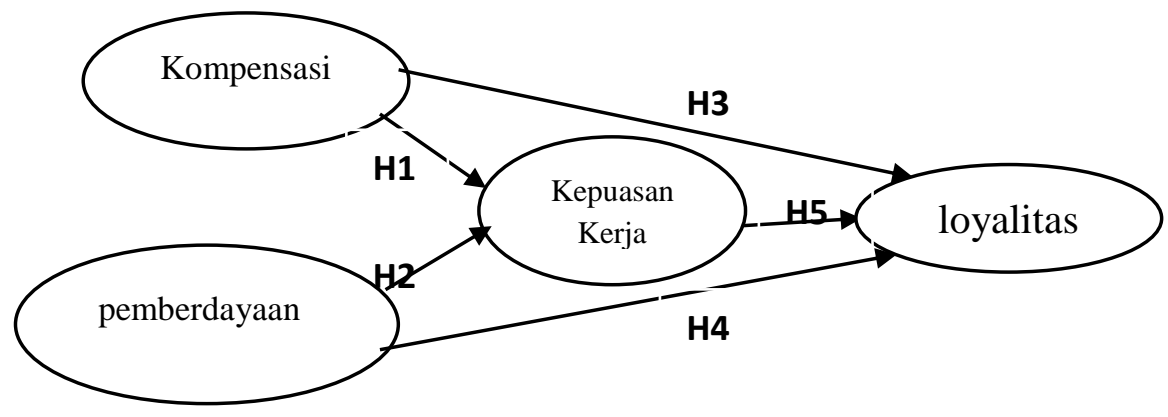

Gambar 1. Kerangka Penelitian

Berdasarkan uraian tersebut, maka hipotesis penelitian adalah sebagai berikut :

$\mathrm{H}_{1} \quad$ : Diduga kompensasi berpengaruh terhadap kepuasan kerja

$\mathrm{H}_{1} \quad$ : Diduga pemberdayaan berpengaruh terhadap kepuasan kerja.

$\mathrm{H}_{1} \quad$ : Diduga kompensasi berpengaruh terhadap loyalitas

$\mathrm{H}_{1} \quad$ : Diduga pemberdayaan berpengaruh terhadap loyalitas.

$\mathrm{H}_{1} \quad$ : Diduga kepuasan kerja berpengaruh terhadap loyalitas

\section{METODE}


Penelitian ini menggunakan metode analisis deskriptif dengan pendekatan kuantitatif. Menurut Malhotra (2005:161) penelitian kuantitatif merupakan metodologi penelitian yang berupaya untuk mengkuantifikasi data dan biasanya menerapkan bentuk statistik analisis tertentu. Variabel yang diteliti adalah kompensasi $\left(\mathrm{X}_{1}\right)$, pemberdayaan $\left(\mathrm{X}_{2}\right)$, kepuasan kerja $\left(\mathrm{Y}_{1}\right)$ dan loyalitas $\left(\mathrm{Y}_{2}\right)$, Dengan subyek penelitian ini adalah pegawai PNS Dinas Pekerjaan Umum dan Penataan Ruang bagian sekertariat yang berjumlah 35 orang.

Teknik pengumpulan data yang digunakan dalam penelitian ini adalah:

a. Kuesioner

Kuesioner adalah teknik pengumpulan data berdasarkan pada jawaban responden atas sejumlah pernyataan yang diajukan mengenai masalah penelitian yang diajukan.

b. Wawancara

Wawancara yaitu mengadakan tanya jawab secara langsung dengan responden untuk memperoleh keterangan untuk tujuan penelitian.

\section{Instrumen Penelitian}

a. Uji Validitas

Menurut Ghozali (2005), uji validitas digunakan untuk mengukur sah atau valid tidaknya suatu kuesioner. Suatu kuesioner dikatakan valid jika pernyataan pada kuesioner mampu untuk mengungkapkan sesuatu yang akan diukur oleh kuesioner tersebut. Validitas mengukur apakah pernyataan dalam kuesioner yang sudah dibuat betul-betul dapat mengukur apa yang hendak diukur. Analisis terhadap uji validitas pada penelitian ini dengan menggunakan bantuan programisasi komputer dengan program SPSS 23.00 for Windows, menggunakan Pearson Correlation (Ghozali, 2005).

b. Uji Reliabilitas

Reliabilitas adalah alat untuk mengukur suatu kuesioner yang merupakan indikator dari variabel atau konstruk (Ghozali, 2005). Kuesioner dikatakan reliabel jika terdapat konsistensi atau stabilnya jawaban atas pernyataan karena hendak mengukur hal yang sama. Menurut Ghozali (2005), jika jawaban terhadap indikator ini acak (tidak konsisten) maka dapat dikatakan bahwa tidak reliabel. Teknik pengujian ini menggunakan teknik analisis yang dikembangkan oleh Alpha Cronbach. Hasil perhitungan adalah reliabel bila koefisien alphanya lebih besar dari 0,6 artinya dapat dipercaya dan dapat digunakan sebagai penelitian.

\section{Uji Asumsi Klasik}

a. Uji Multikoleniaritas

Uji multikoleniaritas bertujuan untuk menguji apakah model regresi ditemukan adanya korelasi antar variabel bebas. Model regresi yang baik seharusnya tidak terjadi korelasi di antara variabel bebas. Jika variabel bebas saling berkorelasi, maka variabel ini tidak ortogonal. Variabel ortogonal adalah variabel bebas yang nilai korelasi antar sesama variabel bebas sama dengan nol (0).

b. Uji Heteroskedastisitas

Menurut Ghozali (2005), uji heteroskedastisitas bertujuan untuk menguji apakah dalam model regresi terjadi ketidaksamaan varian dan residual dari satu pengamatan ke pengamatan 
yang lain. Jika variance ke pengamatan lain tetap, maka disebut homokedastisitas. Model regresi yang baik adalah homokedastisitas atau tidak terjadi heteroskedastisitas (Ghozali, 2005).

c. Uji Normalitas

Pengujian ini bertujuan untuk mengetahui apakah data yang digunakan dalam model regresi berdistribusi normal atau tidak (Ghozali, 2005). Model regresi yang baik adalah distribusi normal atau mendekati normal yang dapat diketahui dengan menggunakan grafik normal plot.

\section{Hipotesis}

a. Uji Hipotesis Parsial (t)

Uji t pada dasarnya menunjukkan seberapa jauh pengaruh satu variabel independen secara individual dalam menerangkan variasi varibel dependen (Ghozali, 2011). Dalam pengujian ini dilakukan untuk mengetahui pengaruh secara parsial antar variabel bebas (motivasi intrinsik dan job crafting) terhadap varibel terikat (work engagement) dan person-job fit sebagai variabel mediasi dengan tingkat signifikansi $\alpha=0,05$.

b. Koefisien Determinasi

Koefisien determinasi pada intinya mengukur seberapa jauh kemampuan model dalam menerangkan variasi variabel dependen. Koefisien determinasi $\left(\mathrm{R}^{2}\right)$ dimaksudkan untuk mengetahui tingkat kepadatan paling baik dalam analisis regresi, dimana hal yang ditunjukkan oleh besarnya koefisien determinasi $\left(\mathrm{R}^{2}\right)$ antara 0 (nol) dan 1 (satu).

Koefisien determinasi $\left(\mathrm{R}^{2}\right)$ nol variabel independen sama sekali tidak berpengaruh terhadap variabel dependen. Apabila koefisien determinasi semakin mendekati satu, maka dapat dikatakan variabel independen berpengaruh terhadap variabel dependen. Selain itu koefisien determinasi dipergunakan untuk mengetahui presentase perubahan variabel terikat (Y) yang disebabkan oleh variabel bebas $(\mathrm{X})$.

\section{Analisis Jalur}

Analisis jalur merupakan perluasan dari analisis regresi linier berganda dimana pengunaan analisis adalah untuk menaksir hubungan kausalitas antar variabel (model kausal) yang ditetapkan sebelumnya berdasarkan teori. Analisis jalur sendiri tidak dapat digunakan substitusi bagi peneliti untuk melihat hubungan kausalitas antar variabel. Analisis jalur digunakan untuk menentukan pola hubungan antara tiga atau lebih variabel dan tidak dapat digunakan untuk mengkonfirmasi atau menolak hipotesis kasualitas imajiner.

\section{Analisis Korelasi}

Korelasi merupakan teknik analisis yang termasuk dalam salah satu teknik pengukuran asosiasi/ hubungan (measure of association). Pengukuran asosiasi mengenakan nilai numerik untuk mengetahui tingkatan asosiasi atau kekutan hubungan antara variabel. Dua variabel dikatan berasosiasi jika perilaku variabel yang satu mempengruhi variabel yang lain. Jika tidak terjadi pengaruh, maka kedua variabel tersebut disebut independen.

Korelasi bermanfaat untuk mengukur kekuatan hubungan anatar dua variabel (kadang lebih dari dua) dengan skala-skala tertentu. Kuat lemah hubungan diukur menggunakan jarak 
(range) 0 sampai 1. Korelasi mempunyai kemungkinan pengujian hipotesis dua arah (two tailed). Korelasi searah jika nilai koefisien korelasi ditemukan positif; sebaliknya jika nilai koefisien korelasi negative, korelasi disebut tidak searah.

\section{HASIL DAN PEMBAHASAN}

Analisis kuantitatif diolah dengan perhitungan statistik dengan bantuan komputer dengan program SPSS versi 25, hasil analisis dapat dijelaskan bahwa seluruh pernyataan yang digunakan dalam penelitian ini dinyatakan reliabel, karena besar alpha lebih dari 0,6. responden dalam penelitian ini berumur 20 sampai 30 tahun sebanyak 10 orang dengan presentase $28,6 \%$, berumur 31 sampai 40 tahun sebanyak 7 orang dengan presentase $20 \%$, berumur 41 sampai 50 tahun sebanyak 4 orang dengan presentase $11,4 \%$, dan yang berumur lebih dari 50 tahun sebanyak 14 orang dengan presentase $40 \%$. Jadi responden terbanyak dalam penelitian ini adalah yang berumur lebih dari 50 tahun. Berdasarkan tingkat pendidikan terakhir SMA/SMK sebanyak 14 orang dengan presentase $40 \%$, berpendidikan D3 sebanyak 7 orang dengan presentase $20 \%$, berpendidikan S1 sebanyak 14 orang dengan presentase $40 \%$.menurut masa Kerja kurang dari 5 tahun sebanyak 6 pegawai atau 17,1\%, masa Kerja 6 sampai 10 tahun sebanyak 10 pegawai atau 28,5\%, masa Kerja 11 sampai 15 tahun sebanyak 7 pegawai atau 20 $\%$, dan masa Kerja yang lebih dari 15 tahun sebanyak 12 pegawai atau 34,2\%. Pada uji reabilitas dan validitas semua kueisoner reliable dan valid.

Tabel 1. Hasil Uji t Struktural I

\begin{tabular}{|l|r|r|r|r|r|}
\hline \multirow{2}{*}{ Model } & \multicolumn{2}{|c|}{$\begin{array}{c}\text { Unstandardized } \\
\text { Coefficients }\end{array}$} & $\begin{array}{c}\text { Standardized } \\
\text { Coefficients }\end{array}$ & \multirow{2}{*}{$\mathrm{t}$} & Sig. \\
\cline { 2 - 5 } & \multicolumn{1}{|c|}{$\mathrm{B}$} & Std. Error & \multicolumn{1}{c|}{ Beta } & & \\
\hline \multirow{2}{*}{ (Constant) } & 4.952 & 1.860 & & 2.662 & .012 \\
1 & .358 & .130 & .253 & 2.743 & .010 \\
KOMPENSASI & 1.249 & .154 & .746 & 8.094 & .000 \\
\hline
\end{tabular}

a. Dependent Variable: KEPUASAN

Berdasarkan hasil uji $\mathrm{t}$ substruktural 1 pada tabel diatas, menunjukan bahwa nilai signifikansi untuk variabel kompensasi (X1) sebesar 0,010<0,05 dan diperoleh angka t hitung sebesar 2,734> 2,034, maka variabel kompensasi berpengaruh secara signifikan terhadap kepuasan, sehingga $\mathrm{H} 0$ ditolak $\mathrm{H} 1$ diterima sedangkan variable pemberdayaan (X1) nilai signifikansi sebesar 0,000 0,05 dan diperoleh angaka thitung sebesar 8,094 > 2,034, maka pemberdayaan berpengaruh secara signifikan terhadap kepuasan, sehingga H0 ditolak H1 diterima. 
Tabel 2. Hasil Uji t Struktural II

\begin{tabular}{|l|r|r|r|r|r|}
\hline \multirow{2}{*}{ Model } & \multicolumn{2}{|c|}{$\begin{array}{c}\text { Unstandardized } \\
\text { Coefficients }\end{array}$} \\
& \multicolumn{2}{|c|}{$\begin{array}{c}\text { Coefficients } \\
\text { S }\end{array}$} & $\begin{array}{c}\text { Standardized } \\
\text { Coefficients }\end{array}$ & $\mathrm{t}$ & Sig. \\
\cline { 2 - 5 } & \multicolumn{1}{|c|}{ Std. Error } & \multicolumn{1}{c|}{ Beta } & & \\
\hline \multirow{2}{*}{ (Constant) } & .562 & 2.017 & & .279 & .782 \\
& .291 & .142 & .219 & 2.042 & .050 \\
KOMPENSASI & -.157 & .264 & -.100 & -.595 & .556 \\
PEMBERDAYAAN & .762 & .173 & .812 & 4.394 & .000 \\
\hline
\end{tabular}

a. Dependent Variable: LOYALITAS

Berdasarkan hasil uji t substruktural II pada tabel diatas, menunjukan bahwa nilai signifikansi untuk variabel kompensasi (X1) sebesar 0,050 = 0,05 dan diperoleh thitung sebesar 2,042 < 2,036, maka variabel kompensasi berpengaruh signifikan terhadap Loyalitas, sehingga H0 ditolak H1 diterima, Nilai signifikansi pada variabel pemberdayaan (X2) sebesar 0,556>0,05 dan diperoleh angka thitung sebesar $-0,595<2,036$, maka variabel pemberdayaan tidak berpengaruh terhadap loyalitas, sehingga $\mathrm{H} 0$ diterima $\mathrm{H} 1$ ditolak, sedangkan nilai signifikansi untuk variabel Loyalitas (Y1) sebesar 0,000 < 0,05 dan diperoleh angka thitung 4,394 > 2.036, maka variabel Loyalitas berpengaruh signifikan terhadap kepuasan Kerja, sehingga H0 ditolak H1 diterima.

$\mathrm{R}^{2}$ adalah 0,757, yang berarti sebesar 75,7 \% variabel kepuasan dipengaruhi pemberdayaan dan kompensasi, sedangkan 24,3 \% (100\%-75,7\%) variabel kepuasan dipengaruhi oleh variabel-variabel diluar penelitian ini. diatas besar $\mathrm{R}^{2}$ adalah 0,846 . Yang berarti sebesar 73,5 \% variabel Loyalitas dipengaruhi oleh variabel pemberdayaan, kompensasi dan kepuasan, sedangkan 26,5 \% (100\%-73,5\%) variabel Loyalitas dipengaruhi oleh variabelvariabel diluar model penelitian ini.

Berdasarkan hasil analisis yang telah dilakukan diperoleh angka korelasi antar variabel pemberdayaan dan kompensasi sebesar 0,401 dengan korelasi yang cukup dengan tingkat signifikan $0,017<0,05$ dapat diartikan bahwa variabel tersebut signifikan. Karena angka signifikan yang diperoleh diatas 0,05 .

1) Koefisien regresi variabel kompensasi $\left(P_{2}\right)=0,253$

Koefisien regresi untuk $\mathrm{X}_{1}$ sebesar 0,702 , artinya setiap penambahan 1 satuan likert pada variabel kompensasi $\left(\mathrm{X}_{2}\right)$ akan menambah kepuasan sebesar 0,253

2) Koefisien regresi pemberdayaan $\left(\mathrm{P}_{1}\right)=0,746$

Koefisien regresi untuk $\mathrm{X}_{2}$ sebesar 0,746, artinya setiap penambahan 1 satuan skala likert pada variabel pemberdayaan $\left(\mathrm{X}_{1}\right)$, maka akan menambah kepuasan sebessar 0,289

3) Nilai residu atau error $=0,477$

Nilai residu sebesar 0,228 menunjukan kepuasan yang tidak dapat dijelaskan oleh variabel pemberdayaan $\left(\mathrm{X}_{1}\right)$ dan kompensasi $\left(\mathrm{X}_{2}\right)$ diabaikan atau sama dengan 0 (nol).

Pada Pengujian hipotesis pertama hasil ini menunjukan pemberdayaan berpengaruh signifikan terhadap kepuasan dengan hasil uji $t$ sebesar 2,743 $>t_{\text {tabel }} 2,034$ dengan tingkat signifikansi sebesar $0,010<0,05$ dimana pegawai telah merasa puas dengan tunjangan- 
tunjangan serta asuransi yang diberikan organisasi, sehingga hipotesis $\mathrm{H}_{1}$ diterima. Hasil penelitian ini mendukung penelitian yang dilakukan oleh Muttaqien(2014) yang menyatakan kompensasi berpengaruh positif dan signifikan terhadap kepuasan

Pada pengujian hipotesis kedua menunjukan pemberdayaan berpengaruh signifikan terhadap Loyalitas dengan hasil uji $\mathrm{t}$ sebesar 8,094 $>\mathrm{t}_{\text {tabel }} 2,034$ dengan tingkat signifikansi sebesar 0,000 $<0,05$ yang artinya pegawai diberikan kepercayaan dari kepala dinas untuk menyelesaikan tugasnya sehingga pegawai merasa bahwa dirinya dipercaya mampu menyelesaikan tugas tersebut maka pegawai akan merasa puas akan pekerjaan yang mereka lakukan, sehingga $\mathrm{H}_{1}$ diterima. Hasil penelitian ini mendukung penelitian yang dilakukan oleh Timbowo, Jantje, Bode (2016) yang menyatakan pemberdayaan berpengaruh positif dan signifikan terhadap kepuasan.

Pengujian hipotesis ketiga menunjukan kompensasi berpengaruh signifikan terhadap Loyalitas dengan hasil uji t sebesar 2,042> ttabel 2,036 dengan tingkat signifikansi sebesar $0,050>0,05$ hal ini menjelaskan bahwa kompensasi yang diberikan telah sesuai dengan apa yang mereka harapkan dan sesuai dengan apa yang telah mereka kerjakan di dalam organisasi sehingga mereka akan loyal terhadap pekerjaan mereka, hal ini juga akan berdampak pada organisasi. sehingga hipotesis H1 diterima. Hasil penelitian ini mendukung penelitian yang dilakukan oleh Safitri (2015) yang menyatakan kompensasi berpengaruh positif dan signifikan terhadap loyalitas

Pengujian hipotesis ke empat menunjukan pemberdayaan tidak berpengaruh terhadap Loyalitas dengan hasil uji t sebesar -0595< ttabel 2,036 dengan tingkat signifikansi sebesar $0,556>0,05$ hal ini menjelaskan bahwa pemberdayaan pegawai tidak berpengaruh terhadap Loyalitas. Hasil penelitian ini tidak sejalan dengan penelitian yang dilakukan oleh Widyati, Mukhneri, Nurjannah (2018) yang menyatakan bahwa pemberdayaan berpengaruh positif dan signifikan terhadap loyalitas. Hal ini dikarenakan pegawai sudah mempunyai jabatan dan tunjangan yang membuat mereka loyal, jadi bukan pemberdayaan yang akan membuat mereka loyal dan pemberdayaan juga bisa memberikan dampak negatif kepada pegawai karena dengan wewenang yang diberikan oleh atasan untuk menyelesaikan pekerjaan mereka, untuk sebagian pegawai ini akan menjadi beban tambahan, karena mereka masih membutuhkan pengarahan. Sehingga hipotesis $\mathrm{H}_{1}$ ditolak.

Selanjutnya Pengujian hipotesis kelima menunjukan kepuasan berpengaruh signifikan terhadap loyalitas dengan hasil uji $\mathrm{t}$ sebesar 4,394 $>\mathrm{t}_{\text {tabel }}$ 2,036 dengan tingkat signifikansi sebesar 0,000 > 0,05 hal ini menjelaskan bahwa pegawai sudah merasa puas terhadap apa yang telah mereka kerjakan sehingga mereka akan loyal terhadap pekerjaan mereka, sehingga hipotesis $\mathrm{H}_{1}$ diterima. Hasil penelitian mendukung penelitian yang dilakukan oleh mariana dan Hadi (2015) yang menyatakan korelasi yang signifikan antara variabel kepuasan dengan loyalitas.

\section{KESIMPULAN}

Berdasarkan hasil penelitan dan analisis data yang telah dipaparkan, dapat diambil kesimpulan sebagai berikut :

1. Variabel kompensasi berpengaruh terhadap kepuasan kerja pegawai. Artinya semakin tinggi nilai kompensasi maka semakin meningkatkan kepuasan pegawai.

2. Variabel pemberdayaan berpengaruh terhadap kepuasan kerja pegawai. Artinya semakin tinggi nilai pemberdayaan maka akan semakin meningkatkan kepuasan pegawai.

3. Variabel kompensasi berpengaruh signifikan terhadap Loyalitas pegawai. Artinya semakin tinggi nilai kompensasi maka akan semakin meningkatkan loyalitas pegawai.

4. Variabel pemberdayaan tidak berpengaruh terhadap loyalitas pegawai. Artinya pemberdayaan tidak mempunyai pengaruh terhadap loyalitas pegawai. 
5. Variabel kepuasan kerja mempunyai pengaruh yang signifikan terhadap loyalitas. Artinya semakin tinggi nilai kepuasan kerja maka akan semakin meningkatkan loyalitas pegawai.

\section{Saran}

Berdasarkan penelitian yang telah dilakukan, maka penulis memberikan saran dalam penelitian ini, antara lain:

1. Pemberian kompensasi yang sesuai akan memotivasi pegawai untuk lebih giat bekerja. Karena setiap orang tentunya menginginkan balas jasa yang sesuai dengan hasil kerja yang mereka sudah lakukan dalam kurun waktu tertentu. Jadi, dapat disimpulkan bahwa pemberian kompensasi yang tepat merupakan salah satu cara untuk meningkatkan kepuasan pegawai. Hal ini menunjukan bahwa besarnya kompensasi yang diterima pegawai akan meningkatkan kepuasan terhadap pekerjaan mereka. Hal ini dapat menjadikan pertimbangan pimpinan untuk memberikan kompensasi sesuai dengan yang diharapkan pegawai untuk meningkatkan kepuasan Kerja pegawai.

2. Berdasarkan hasil penelitian menunjukan bahwa pemberdayaan berpengaruh secara signifikan terhadap kepuasan pegawai, hal ini menunjukan bahwa semakin pegawai diberi kepercayaan dan wewenang dari pimpinan maka kepuasan pegawai akan meningkat. Hal ini dapat menjadikan pertimbangan pimpinan untuk lebih memperhatikan pemberdayaan terhadap pegawainya agar kepuasan Kerja pegawai semakin tinggi

3. Berdasarkan hasil penelitian menunjukan bahwa pemberdayaan berpengaruh secara signifikan terhadap kepuasan pegawai. Hal ini menunjukan bahwa semakin pegawai diberi kepercayaan dan wewenang dari pimpinan maka kepuasan pegawai akan meningkat. Hal ini dapat menjadikan pertimbangan pimpinan untuk lebih memperhatikan pemberdayaan terhadap pegawainya agar kepuasan kerja pegawai semakin tinggi.

4. Berdasarkan hasil penelitian menunjukan bahwa kepuasan berpengaruh terhadap loyalitas kerja pegawai. Hal ini menunjukan bahwa apabila kepuasan pegawai telah terpenuhi maka loyalitas kerja akan semakin baik, dimana pegawai sudah merasa puas dengan penempatan kerja yang sesuai dengan keahliaanya, serta lingkungan Kerja yang mendukung. Hal ini dapat dijadikan masukan bagi kepala dinas untuk meningkatkan kepuasan pegawainya misalya dengan menambah fasilitas yang ada di tempat kerja agar pegawai merasa puas dengan suasana tempat kerja mereka.

5. Pada penelitian selanjutnya diharapkan dapat menambah atau mencari variabel lain di luar variabel penelitian yang telah dilakukan seperti pelatiha, lingkungan kerja dan lain-lain. Karena diduga masih banyak variabel lain yang mempengaruhi kepuasan dan loyalitas kerja pegawai. Serta menambah teori secara lebih lengkap yang mendukung dalam penelitian. Selain itu, penelitian selanjutnya diharapkan dapat menguji pada sampel atau tempat lainnya seperti manufaktur, kewirausahaan, keperawatan ataupun kantor lainnya.

\section{REFERENSI}

Anak, N. B. D., et all. 2012. "Pengaruh Motivasi, Lingkungan Kerja, Kompetensi, Dan Kompensasi Terhadap Kepuasan Kerja Dan Kinerja Pegawai Di Lingkungan Kantor Dinas Pekerjaan Umum Provinsi Bali." Jurnal Manajemen, Strategi Bisnis, dan Kewirausahaan. Vol. 6, No. 2. Diunduh 5 Februari 2020.

Angelia, S. P., et all. 2018. "Pengaruh Lingkungan Kerja, Pelatihan, Dan Pemberdayaan Sdm Terhadap Kepuasan Kerja Karyawan Pt. Pln (Persero) Wilayah Suluttenggo.”Jurnal $E M B A$. Vol.6 No.3. Diunduh 5 Februari 2020. 
Ardana, I.K., et all.2012. Manajemen Sumber Daya Manusia. Edisi Pertama. Yogyakarta: Graha Ilmu.

Davis, Keith dan Newstrom. 1985. Perilaku dalam Organisasi. Jakarta: Erlangga.

Dessler, G. 2000. Manajemen Sumber Daya Manusia Jilid 1. Jakarta: Indeks.

. 2007. Manajemen Sumber Daya Manusia Edisi Bahasa Indonesia Jilid 2. Edisi 10. Jakarta: PT Indeks. (terj.). 1997. Manajemen Sumber Daya Manusia. Jakarta: PT Prenhallind

Ester W., et all. 2018. "Pengaruh Pemberdayaan Dan Kepercayaan Terhadap Loyalitas Guru SMA Swasta di Kecamatan Pulogadung Jakarta Timur." Jurnal Ilmiah Wawasan Pendidikan . Vol 4, No.3. Diunduh 5 Februari 2020.

Fauzan M. 2014. "Pengaruh Kepemimpinan Dan Kompensasi Terhadap Kepuasan Kerja Karyawan Outsourcing Pada Pt. Bri (Persero), Tbk. Cabang Lumajang.” Jurnal WIGA. Vol. 4 No.1. Diunduh 5 Februari 2020.

Fernando, S. L. 2013. "Pengaruh Pelatihan, Pemberdayaan Dan Efikasi Diri Terhadap Kepuasan Kerja." Jurnal EMBA. Vol.1 No. 3. Diambil 13 Oktober 2018.

Gibson, James. L et. al. (terj.). 2012. Organisasi: Perilaku, Struktur, Prose. Jakarta: Binarupa Aksara.

Ghozali, Imam. 2005. Aplikasi Analisis Multivariate dengan Program SPSS, Semarang: Badan Penerbit UNDIP

2011. Edisi 5. Aplikasi Analisis Multivariate dengan Program IBM SPSS 19. Semarang: Badan Penerbit UNDIP

Handoko, T., Hani, 1998, Manajemen Sumber Daya Manusia. Yogyakarta: Liberty. . 2000. Manajemen Sumber Daya Manusia. Yogyakarta: BPFE.

Hasibuan, Malayu S.P 2016. Manajemen Sumber Daya Manusia. Edisi Revisi. Jakarta: PT Bumi Aksara. 2006. Manajemen Sumber Daya Manusia. Jakarta: Erlangga. . 2001. Manajemen Sumber Daya Manusia. Jakarta: PT Bumi Aksara. .2011. MANAJEMEN: Dasar, Pengertian, dan Masalah. Jakarta: PT Aksara.

Jewell. L. N. \& Siegall. M. 1998. Psikologi Industri/Organisasi Moderen: Psikologi Penerapan untuk Memecahkan Berbagai Masalah di tempat Kerja, Perusahaan, Industri dan Organisasi. Edisi ke 2. Jakarta: Arcan.

Khan, Rabia I., et al. 2011. "Compensation Management: A Strategic Conduit Towards Achieving Employee Retention and Job Satisfaction In Banking Sector Of Pakistan."International Journal of Human Resource Studies. 
Kreitner, Robert dan Kinicki, Angelo. 2005. Perilaku Organisasi. Buku 1. Edisi Kelima. Jakarta: Salemba Empat.

Lutfan, D. S., et all. 2018. "Pengaruh Keselamatan Dan Kesehatan Kerja (K3) Dan Kompensasi Terhadap Kepuasan Kerja Karyawan Pt Solo Murni.” Diunduh 5 Februari 2020.

Luthans, Fred. 2006. Perilaku Organisasi. Edisi kesepuluh. Yogyakarta: Andi.

Mangkunegara, A.A. 2000. Manajemen Sumber Daya Manusia Perusahaan. Bandung: Rosdakarya.

Mahardian. 2004. Faktor-faktor yang mempengaruhi pemberdayaan karyawan. Jakarta: Salemba Empat.

Mathis, R. L., Jackson, J. H., \& Valentine, S. R. 2014. Human Resource Management. Boston, MA: Cengage Learning.

Mei R. W. W., et all. 2010. "Pengaruh Stres Kerja Dan Pemberdayaan Terhadap Kepuasan Kerja Karyawati Call Center Di Pt 'X' Surabaya." Jurnal Bisnis dan Manajemen. Vol. 2, No. 2. Diunduh 6 Februari 2020.

Mondy, R Wayne. 2008. Manajemen Sumber Daya Manusia. Jilid 2. Edisi 10. Jakarta: Erlangga.

Peraturan Pemerintah RI Nomor 46 Tahun 2011 tentang Penilaian Pelaksanaan pekerjaan pegawai Negeri Sipil (PNS). Dari http: www.humkumonline.com.

Phillips, Jean. M \& Gully, Stanley M. (terj.). 2012. Organizational Behavior. South Western: Cengage Learning.

Rahmadana S. 2015. "Pengaruh Kompensasi Terhadap Loyalitas Karyawan Pt. Putera Lautan Kumala Lines Samarinda.” eJournal Administrasi Bisnis. Diunduh 10 Februari 2020.

Rivai, Veithzal. 2011, Manajemen Sumber Daya Manusia: dari teori ke Praktik, Jakarta : Raja Grafindo Persada

Rizwan, Arshad, et all. 2014. "Factors Influencing Job Satisfaction and Its Impact on Job Loyalty.” International Journal of Learning \& Development. Vol. 4, No. 2. Diunduh 5 Februari 2020

Robbins, Stephen P \& Coulter, Mary. 2016. Manajemen (jilid 1). Edisi 13. Jakarta: Erlangga . 2003. Perilaku Organisasi. Index. Jakarta.

Rizwan A., et al. 2014. "Factors Influencing Job Satisfaction and Its Impact on Job Loyalty." International Journal of Learning \& Development. Vol. 4. Diunduh 5 Februari 2020.

Schermerhorn , John R., et al. (terj.). 2012. Organizational Behavior. Asia: John Wiley \& Sons, Inc.

Simamora, Henry. 2004. Manajemen Sumber Daya Manusia. Edisi Kedua. Cetakan kesembilan. Yogyakarta: YKPN. 
Soegandhi, Vannecia. M. dkk. 2013. "Pengaruh Kepuasan Kerja dan Loyalitas Kerja terhadap Organizational Citizenship Behavior pada Karyawan PT Surya Timur Jatim." Vol 1. Nomor 1. Program Studi Manajemen. Univ. Kristen Petra.

Sugiyono, 2010. Metode Penelitian pendidikan pendekatan Kuantitatif, Kualitatif, dan R\&D. Bandung: Alfabeta

Suwanto dan Priansa, D. 2013. Manajemen Sumber Daya Manusia dalam Organisasi Publik dan Bisnis. Bandung: Alfabeta.

Silviana, D. 2018. "Pengaruh Promosi Jabatan Dan Kompensasi Terhadap Kepuasan Kerja Karyawan Pada Pt. Perwita Margasakti Jakarta.” Jurnal Visionida. Vol.4 No.1. Diunduh 5 Februari 2020.

Syadam, Gouzali. 2011. Manajemen Sumber Daya Manusia suatu pendekatan Mikro. Jakarta: Djanbatan.

Wibowo. 2007. Manajemen Kinerja. Jakarta: Raja Grafindo Parsada.

Zabdy, S. T., et all. 2016. "Pengaruh Lingkungan Kerja, Pelatihan, Dan Pemberdayaan Sdm Terhadap Kepuasan Kerja Karyawan Pada Pt. Bank Bca Tbk. Manado.” Jurnal EMBA. Vol.5 No.1. Diunduh 5 Februari 2020. 